Семчинський Костянтин Валерійович

кандидат філософських наук, дочент,

Київський національний університет культури і мистещтв,

Київ, Украӥна,

semchynskyy@gmail.com

\title{
ОСОБЛИВОСТІ ПРИМИРЕННЯ І МИРОБУДІВНИЦТВА В УМОВАХ ЗАМОРОЖЕНИХ КОНФЛІКТІВ НА ПОСТРАДЯНСЬКОМУ ПРОСТОРІ
}

В умовах російської агресії проти України особливості миробудівництва та перспективи постконфліктного примирення на пострадянському просторі постають сьогодні актуальними питаннями. Метою дослідження є виявити особливості миробудівничих ініціатив у зонах нині заморожених конфліктів на пострадянському просторі, визначити напрями і механізм успішного миробудівництва і запропонувати ефективні кроки й елементи стратегії постконфліктного примирення. Застосувавши системні, аналітичні і компаративні методи, автор обгрунтовує необхідність формування комплексної стратегії постконфліктного примирення у кожній із зон конфліктної взаємодії на пострадянському просторі. У результаті дослідження автор визначає мирне врегулювання та відновлення справедливості магістральними напрямами успішного миробудівництва у зонах тліючих конфліктів на пострадянському просторі, механізм якого має включати елементи стратегії пост-конфліктного примирення у зонах нині заморожених конфліктів. Виявлено, що миробудівничі ініціативи формуватимуть світоглядно-ціннісну та нормативно-адміністративну платформу для ефективного i успішного пост-конфліктного примирення. У висновках наводяться такі ефективні кроки для успішного миробудівництва, а у перспективі - пост-конфліктного примирення: досягнення мирних домовленостей між ворогуючими сторонами; комплекс заходів щодо роззброєння та повернення до мирного життя учасників незаконних збройних формувань; формування адекватних виборчої і партійної систем; зміцнення демократії в цілому та засоби проти рецидиву конфлікту у майбутньому. Водночас, автор робить висновок про те, що постконфліктне примирення в умовах замороженого конфлікту в повній мірі не є здійсненним, оскільки деякі з базових заходів, необхідних для ефективного постконфліктного будівництва і примирення, реалізувати технічно складно або взагалі неможливо. Авторською знахідкою є окреслення концепту «меморіалізації» пам’яті про конфлікт як надійного запобіжника проти рецидиву конфлікту у майбутньому.

Ключові слова: конфлікт, пост-конфліктне примирення, миробудівництво, стратегія примирення, пострадянський простір.

Semchynskyi Kostyantyn, Candidate of Philosophy, Associated Professor, Kyiv National University of Culture and Arts, Kyiv, Ukraine

The features of reconciliation and peace building in conditions of frozen conflicts on the post-Soviet territory

Under the conditions of Russian aggression against Ukraine, the peculiarities of peace building and the prospects of post-conflict reconciliation on the post-Soviet space are significant today. The main objectives of the study are: to identify the peculiarities of peace building initiatives in the zones of now frozen conflicts in the post-Soviet area, to determine the directions and mechanism of successful peace building, and to propose effective steps and elements of the strategy of post-conflict reconciliation. By applying systematic, analytical and comparative methods, the author justifies the necessity of forming a comprehensive strategy of post-conflict reconciliation in each of the zones of conflict interaction in the post-Soviet space. As a result of the study, the author determines the peaceful settlement and restoration of justice as the main directions of successful peace building in the zones of fractious conflicts in the 
post-Soviet space, the mechanism of which must include elements of the strategy of post-conflict reconciliation in the zones of frozen conflicts. It is revealed that peace building initiatives will form a world-view, value, and regulatory-administrative platform for effective and successful post-conflict reconciliation. The conclusions provide such effective steps for successful peace building, and in the long run- post-conflict reconciliation: the achievement of peace agreements between the warring parties; a package of measures for disarmament and the return to peaceful life of members of illegal armed groups; the formation of adequate election and party systems; the consolidation of democracy in general and the means to prevent a recurrence of conflict in the future. At the same time, the author concludes that postconflict reconciliation in a frozen conflict is not fully feasible, since some of the basic measures needed for effective post-conflict building and reconciliation are technically difficult or impossible to implement at all. The author's finding is the outline of the concept of memorializing the memory of the conflict as a reliable fuse against the relapse of the conflict in the future.

Key words: conflict, post-conflict reconciliation, peace building, reconciliation strategy, postSoviet space.

Семчинский Костянтин Валерьевич, кандидат философских наук, доцент, Киевский национальный университет культуры и искусств, Киев, Украина

\section{Особенности примирения и строительства мира в условиях замороженных} конфликтов на постсоветском пространстве

В условиях российской агрессии против Украины особенности строительству мира и перспективы постконфликтного примирения на постсоветском пространстве являются сегодня актуальными вопросами. Целью исследования является выявить особенности миротворческих инициатив в зонах ныне замороженных конфликтов на постсоветском пространстве, определить направления и механизм успешного строительства мира и предложить эффективные шаги и элементы стратегии постконфликтного примирения. Применив системные, аналитические и компаративные методы, автор обосновывает необходимость формирования комплексной стратегии постконфликтного примирения в каждой из зон конфликтного взаимодействия на постсоветском пространстве. В результате исследования автор определяет мирное урегулирование и восстановление справедливости магистральными направлениями успешного строительства мира в зонах тлеющих конфликтов на постсоветском пространстве, механизм которого должен включать элементы стратегии постконфликтного примирения в зонах ныне замороженных конфликтов. Выявлено, что миротворческие инициативы формировать мировоззренческиценностную и нормативно-административную платформу для эффективного и успешного постконфликтного примирения. В заключении приводятся такие эффективные шаги для успешного строительства мира, а в перспективе - пост-конфликтного примирения: достижение мирных договоренностей между враждующими сторонами; комплекс мероприятий по разоружению и возвращению к мирной жизни участников незаконных вооруженных формирований; формирование адекватных избирательной и партийной систем; укрепление демократии в целом и средства против рецидива конфликта в будущем. В то же время, автор делает вывод о том, что постконфликтное примирения в условиях замороженного конфликта в полной мере не является осуществимым, поскольку некоторые из базовых мер, необходимых для эффективного постконфликтного строительства и примирения, реализовать технически сложно или вообще невозможно. Авторской находкой является определение концепта «мемориализации» памяти о конфликте как надежного предохранителя против рецидива конфликта в будущем.

Ключевые слова: конфликт, постконфликтное примирение, строительство мира, стратегия примирения, постсоветское пространство.

Вступ. Заморожені конфлікти на Південному Кавказі, у Придністров’ї та в Україні є інструментом поширення і збереження імперського впливу РФ на пострадянському просторі. Водночас, прагнення до примирення задля конструктивного миробудівництва $є$ природним у 
спільнотах, розділених цими конфліктами. Оскільки інспірований Кремлем на території нашої держави конфлікт наразі переходить у латентну стадію, постає актуальним як дослідити саму можливість постконфліктного примирення у зонах заморожених конфліктів, так і окреслити особливості миробудівництва на окупованих нині українських землях.

В останніх дослідженнях і публікаціях започатковано розв'язання цісї проблеми 3 акцентом на питанні постконфлікного врегулювання, відбудови i миробудівництва в зоні замороженого конфлікту на Сході України [3; 8] або ж подаються характеристики конфліктів на пострадянському просторі $[5 ; 6 ; 10 ; 11]$. Чи не єдина робота, присвячена миротворчим практикам саме у зоні замороженого - нагірно-карабаського - конфлікту: кейс Айтан Гахраманової [9].

Заморожені конфлікти на пострадянському просторі в цілому вичерпно досліджуються зарубіжними і вітчизняними політологами: геополітичні інтереси РФ у зоні «заморожених» конфліктів на пострадянському просторі досліджувались В. Алєксєйченком, а пошуки моделі вирішення етнотериторіальних конфліктівна пострадянському просторі - В. Нагорняком. Серед вітчизняних авторів, що досліджували проблематику пост-конфліктного врегулювання в регіоні, варто зазначити А. Кіссе (Особливості та основні сценарії розгортання етнічного конфлікту в постсоціалістичних країнах).

Анексія Росією Криму та ії агресія на Сході України дали поштовх низці нових наукових досліджень i публікацій зарубіжних і вітчизняних авторів, присвячених різного роду ретроспективним і порівняльним аналізам заморожених (або ж тліючих) конфліктів, інспірованих Росією на пострадянському просторі $[1 ; 5 ; 6 ; 10 ; 11]$. Особливої уваги заслуговує аналітична записка НІСД «Припинення i постконфліктне врегулювання сепаратистських конфліктів: іноземний досвід і висновки для України» [7], автори якої розглядають міжнародну практику щодо припинення регіональних конфліктів на сепаратистському грунті та механізми постконфліктного врегулювання суспільно-політичної й економічної ситуації у постраждалих регіонах. Пропонується досвід держав, які здебільшого подолали стадію внутрішнього конфліктного протистояння і наразі активно розбудовують мир - Нікарагуа, Бангладеш, Камбоджі, Еритреї, ПАР, Анголи, Хорватії, Боснії, Македонії, Північної Ірландії. Однак пострадянський простір у таких дослідженнях представлений лише східноукраїнським конфліктом, а про заморожені конфлікти не йдеться взагалі.

Бракує праць, які б досліджували миробудівництво у зонах латентної конфліктної взаємодії на пострадянському просторі та визначали б конкретні кроки постконфліктного примирення у перспективі врегулювання конфлікту. Виходячи із цього, автор ставить перед собою такі завдання:

- виявити особливості миробудівничих ініціатив у зонах заморожених конфліктів на пострадянському просторі;

- визначити магістральні напрями успішного миробудівництва у зонах тліючих конфліктів на пострадянському просторі та окреслити його механізм;

- запропонувати ефективні кроки й елементи стратегії постконфліктного примирення у зонах нині заморожених конфліктів.

У міжнародних відносинах заморожений конфлікт визначається як ситуація, коли активний збройний конфлікт було припинено, але не було ані підписано мирний договір, ані прийнято іншого компромісного політичного рішення, яке б задовольнило сторони конфлікту. Ситуація, при якій збройне протистояння не стоїть на порядку денному, проте може розпочатися внаслідок провокації та у короткі терміни перетворити тліючий конфлікт на гарячу точку планети, створює середовище незахищеності та нестабільності.

Постконфліктне примирення в умовах замороженого конфлікту в повній мірі не $\epsilon$ здійсненним, оскільки деякі з базових заходів, необхідних для ефективного постконфліктного будівництва і примирення, реалізувати технічно складно або взагалі неможливо. Наприклад, РФ не ініціюватиме примирення між сторонами заморожених конфліктів, оскільки проведення демократичних виборів у зонах конфлікту може зруйнувати такий звичний для неї інструмент 
дестабілізації і тиску на сторони конфлікту, невизнані анклави і регіон в цілому. Набагато вигідніше підтримувати стан «ані війни, ані миру», консервувати стан невизначеності i нестабільності з метою збереження своєї присутності і поширення свого впливу. До того ж мешканці конфліктних зон часто сприймають Росію як захисника і добродійника, а багато росіян легко піддаються кремлівській неправдивій пропаганді 3 нав'язування думки про нагальність та необхідність захисту колишніх співвітчизників: така обопільна зацікавленість у російському факторі робить марними будь-які спроби остаточно врегулювати конфлікт. До цього можна додати колись вдалі спроби Москви вплинути на європейських та американських політиків, міжнародні установи у таких спосіб, щоб складалося враження, що лише Росія може владнати та вирішити такий конфлікт.

Звичайно, міцні зв'язки із «сепаратистами», яких саме Росія постачає або ж винаймає, глибокі знання щодо пострадянського середовища, мови, історичної культури, разом із вимогою до світу визнати сферу російських інтересів на пострадянському просторі якийсь час могли створювати ілюзію вагомого аргументу присутності Росії для «вирішення» конфлікту. Однак, завданням, яке ставила перед собою Москва, було не врегулювання конфлікту, а створення нових регіональних конфліктів, замаскованих як місцевий сепаратизм. Тому, коли, не втримавшись перед спокусою, Росія успішно анексувала Крим, у Кремля виникла необхідність терміново створити нове вогнище конфліктної взаємодії на Сході України. Тобто сама анексія тієї чи іншої території не є кінцевою метою конфлікту, планованого Росією, оскільки не відповідає стратегічним інтересам Кремля, адже неврегульовані конфлікти надають останньому можливість впливати на політику тієї чи іншої пострадянської держави упродовж багатьох років. Виходячи 3 цього, можна зробити висновок, що війна з Грузією 2008 року завершилася для РФ стратегічною поразкою, оскільки Абхазія і Південна Осетія проголосили незалежність, яку Росія не могла не визнати. Грузія визнала фактичну втрату цих територій, позбавивши таким чином Кремль можливості використовувати тліючий конфлікт у своїх інтересах.

Аналізуючи заморожені конфлікти на пострадянському просторі (Придністров'я, Нагірний Карабах, Абхазія та Південна Осетія) мусимо визнати, що про постконфліктне примирення у повному обсязі в кожному із випадків говорити зарано через низку причин. Проте $є$ сенс концентруватися на миробудівництві, тому що магістральні аспекти розбудови миру по суті є або створенням фундаменту для замирення та майбутньої реінтеграції регіону, або навіть своєрідним «продовженням» процесу постконфліктного примирення, коли головного результату - а саме суспільного консенсусу i створення надійних запобіжників проти рецидиву конфлікту у майбутньому - було досягнуто. Крім того, миробудівничі ініціативи формуватимуть світоглядноціннісну та нормативно-адміністративну платформу для ефективного i успішного постконфліктного примирення. До того ж, на наше глибоке переконання, завчасно писати $\mathrm{i}$ говорити про пост-конфліктне примирення у зонах заморожених конфліктів на пострадянському просторі необхідно і доречно з огляду на перспективу остаточного врегулювання цих конфліктів.

Особливістю миробудівництва на пострадянському просторі, а в подальшій перспективі також і постконфліктного примирення, $є$ те, що на думку ряду дослідників $[1 ; 6 ; 11]$ «заморожені конфлікти не такі вже й заморожені», тобто вони відносно легко та блискавично можуть повернутися в «гарячу» стадію відкритого конфлікту. У цьому контексті варто нагадати, що грузинсько-абхазький та грузинсько-південно-осетинський конфлікти із початку 1990-х pp. і аж до серпня 2008 р. перебували у замороженому стані. Нагірно-карабаський конфлікт періодично «розморожується» внаслідок російських впливів на сторони й геополітичної архітектоніки Південного Кавказу в цілому. В останне це сталося навесні 2016 р., коли прикордонні сутички забрали життя декількох десятків осіб з обох сторін. Факти кровопролиття не наближують, а скоріше віддаляють розв'язання конфлікту, і такий тривалий розбрат на Кавказі теж вигідний Москві.

Сценарій розвитку подій у Придністровському регіоні Молдови у 1992 р. дуже нагадує те, що відбувається сьогодні на Донбасі. РФ як посередник у переговорному процесі наполегливо 
виступає проти заміни російських миротворців у зоні Придністровського конфлікту на міжнародну місію цивільних спостерігачів і з найвищих трибун постійно заявляє про цілковиту підтримку суверенітету та територіальної цілісності Молдови у загальновизнаних міжнародним співтовариством кордонах. Однак, як і у випадку із Донбасом, це Кремль продовжує надавати постійну політичну, фінансову, воєнну підтримку самопроголошеній Придністровській Молдавській республіці (ПМР), а лідерів невизнаного Придністров'я, як і ватажків терористів 3 ОРДЛО, в Москві приймають як керівників окремої, нехай і ніким не визнаної, держави. Відсутність в українському суспільстві консенсусу щодо примирення і миробудівництва на Донбасі корелює із подібними тенденціями у Молдові щодо Придністров'я.

Придністровський конфлікт, активна фаза протистояння якого завершилась понад чверть століття тому, розділив Молдову по Дністру. На правому березі - конституційна влада Молдови, що захищає сьогодні незалежність, суверенітет і територіальну цілісність держави. На лівому самопроголошена ПМР, яка шляхом проведення референдуму у 2006 р. оголосила про свою повну незалежність і не приховує наміру в майбутньому приєднатися до Росії. Щоправда, 11 років по тому Президент Молдови I. Додон заявив, що Придністров'я не може увійти до складу Росії, а повинне визначитися між Україною та Молдовою [2]. Не можна наразі виключати такого розвитку подій, за якого Росія в своєму прагненні перешкодити розширенню ЄС і НАТО на Схід спробує зробити з Придністровського регіону Молдови політико-адміністративне утворення на кшталт російської Калінінградської області, територіально не поєднаної із рештою Росії. Проте, попри невизначеність і невизнаність Придністров'я, нині жителі обох берегів Дністра мирно взаємодіють на побутовому рівні, залагоджують особисті відносини між представниками Молдови й Придністров'я та підтримують локальні економічні зв'язки.

Подібність сценаріїв нині заморожених конфліктів на пострадянському просторі дає підстави говорити про можливість повторення цього сценарію із заморожуванням ще одного конфлікту - на Сході України. Миробудівничі ініціативи в суспільних системах, уражених тривалими тліючими конфліктами, мають створити міцне підгрунтя для постконфліктного примирення, своєю чергою включаючи, перш за все, досягнення мирних домовленостей між ворогуючими сторонами і комплекс заходів щодо роззброєння та повернення до мирного життя учасників незаконних збройних формувань у зонах заморожених конфліктів. Беручи до уваги характер і кількість зброї, а також домінуючі нині у зонах тліючих конфліктів суспільні настрої, сам процес роззброєння може відбуватися паралельно або навіть після соціальної реабілітації та адаптації учасників незаконних збройних формувань до мирного життя.

Демократичні вибори покликані відновити громадянський мир та активізувати реінтеграцію постконфліктних територій. Водночас передчасна організація волевиявлення місцевого населення, так само, як і недостатня та неналежна підготовка до виборів, може не лише не сприяти примиренню та реінтеграції, а навпаки спровокувати додаткове джерело конфронтації та відновити активну фазу бойових дій. Деякі дослідники [4] пропонують надати право до офіційних перемовин із миробудівництва екстремістськім групам, які $\epsilon$ безпосередніми порушниками миру та зацікавленні у підтриманні конфлікту, наприклад, представникам проросійських сепаратистів. Проте ми не можемо погодитися із залученням учасників терористичних формувань до участі у демократичних виборах, від результатів яких залежатиме майбутнє як регіону, так і України в цілому. Терористи, які чинили злочини проти людяності, піддавали жорстоким тортурам і вбивали учасників АТО й місцеве мирне населення, мають понести відповідне до своїх злочинів покарання.

Суспільства, зруйновані чи знекровлені тривалим протистоянням, стоять перед дилемою: (1) відновити справедливість і покарати злочинців чи (2) визнати пріоритетом збереження єдності суспільства. У такому випадку існує три основних варіанти вирішення дилеми: по-перше, покарання злочинців у рамках національної судової системи чи міжнародних організацій; подруге, створення комісій правди, членами яких можуть стати безпосередні учасники та свідки конфлікту, які докладуть зусиль для відтворення правдивої історичної картини та визначатимуть 
суспільне (громадянське) покарання, моральну чи матеріальну ретрибуцію жертвам від тих, хто завдав їм шкоди, чи амністію; третій шлях - національна амнезія, тобто відмова ворушити минуле, оцінювати дії воюючих сторін, що, як правило, супроводжується амністією всіх учасників конфлікту. На жаль, третій варіант у чистому вигляді може підтримувати приховане напруження у суспільстві упродовж багатьох років, позаяк ті, хто постраждали від конфлікту, можуть відчувати несправедливість такого вирішення, а ті, що скоїли злочини, або переконаються у власній безкарності, або будуть нести тягар вини. Балансування між покаранням і амністією - це єдиний шлях, яким постраждале суспільство зможе прийняти своє минуле.

Виходячи з цього, наголосимо, що в Молдові, Україні, Грузії, Вірменії та Азербайджані має бути розроблена комплексна програма примирення, до складу якої мають увійти критерії амністії до учасників збройних конфліктів та відповідні нормативні акти на законодавчому рівні. Комплекс заходів має передбачати, зокрема: притягнення до відповідальності осіб, які скоїли злочини проти людяності; недопущення таємних домовленостей щодо надання імунітету окремим особам; відкритість, прозорість і громадське обговорення; чіткі часові межі проведення амністії тощо.

Важливим моментом розбудови миру повинно стати правдиве інформування того чи іншого регіону щодо політичних та економічних успіхів України (Молдови, Грузії), плекання доброзичливого ставлення суспільства до колишніх (і майбутніх) співвітчизників, налагодження економічних та особистих зв'язків на низинному рівні.

Задля успішного постконфліктного примирення у майбутньому, миробудівництво в умовах замороженого конфлікту має вирішити такі суспільнозначущі завдання: запобігти фальсифікації історії (героїзації своєї поведінки) однією з сторін; дати змогу жертвам розказати про пережите задля виявлення максимально правдивої картини подій; сприяти усуненню причетних до злочинів із займаних посад та формуванню колективної відповідальності замість обвинувачення у кровопролитті одного з учасників конфлікту.

Миробудівничі ініціативи у зонах заморожених конфліктів на пострадянському просторі мають грунтуватися на принципах компромісу і взаємної поваги. Кожна сторона повинна чітко усвідомлювати свої цілі та запити, необхідно уникати тиску на сторони для отримання обіцянок, які вони навряд чи зможуть виконати і замість того, щоб ділити ресурси, які важливі для обох сторін, потрібно створити майданчик для спільного їх використання.

Створення Інститутів пам'яті, меморіалів геноциду чи громадянських воєн, якщо ці інституції не $є$ політично ангажованими на користь якоїсь з сторін минулого конфлікту, увіковічення пам'яті про конфлікт у мистецьких творах, шкільних програмах, концепціях національної безпеки - об'єктивно, неупереджено та без зайвої героїзації і демонізації учасників усе це виступає потужними засобами суспільної меморіалізаиї̈ пам'яті про конфлікт, яка слугує надійним запобіжником проти рецидиву конфлікту у майбутньому.

Висновки i пропозиції. Заморожені конфлікти на пострадянському просторі- це інструмент впливу Росії на країни, що вибороли свою незалежність, і зони конфлікту в них створюються Кремлем для просування інтересів Росії. У будь-який момент нове протистояння на основі того старого, що було призупинене, може отримати від Росії новий поштовх для розгортання, і цей факт політичної хиткості районів заморожених конфліктів легко дестабілізує ситуацію. Саме загроза ескалації замороженого конфлікту детермінує низку особливостей як миробудівництва у зоні конфлікту, так і пост-конфліктного примирення у випадку остаточного врегулювання конфлікту.

Мирне врегулювання і трансформація насильницького конфлікту шляхом перетворення його із деструктивного на конструктивний та відновлення справедливості визначено магістральними напрямами успішного миробудівництва у зонах тліючих конфліктів на пострадянському просторі. Механізм його має включати елементи стратегії постконфліктного примирення у зонах нині заморожених конфліктів. 
Програма постконфліктного примирення має містити такі ефективні кроки: досягнення мирних домовленостей між ворогуючими сторонами; комплекс заходів щодо роззброєння та повернення до мирного життя учасників незаконних збройних формувань; формування адекватних виборчої і партійної систем; зміцнення демократії в цілому та засоби проти рецидиву конфлікту у майбутньому.

\section{Список використаних джерел:}

1. Горбулін В. Гібридна війна: все тільки починається... [Електронний ресурс] / В. Горбулін // Дзеркало тижня. - Режим доступу: https://dt.ua/internal/gibridna-viyna-vse-tilkipochinayetsya-_.html. - Назва з екрану. - Дата звернення 20.12.2017.

2. Додон I. Придністров'я може стати частиною або України, або Молдови, але не РФ [Електронний ресурс] / І. Додон // Цензор. нет. - Режим доступу: https://ua.censor.net.ua/n462739. Назва з екрану. - Дата звернення 23.12.2017.

3. Донбас в етнополітичному вимірі. - Київ: ІПіЕНД ім. І. Ф. Кураса НАН України, 2014. $584 \mathrm{c}$.

4. «Дорожня карта» вирішення Східноукраїнського конфлікту як форма організації громадянської активності [Електронний ресурс] // УІСГРА. - Режим доступу: https://uisgda.com/ua/dorozhnya-karta-virishennya-shidnoukrainskogo-konfliktu-yak-forma-organizaciigromadyanskoi-aktivnosti.html. - Назва з екрану. - Дата звернення 10.01.2018.

5. Досвід врегулювання конфліктів у світі. Уроки для України [Електронний ресурс] // Інститут світової політики. - Режим доступу: https://glavcom.ua/media/o-00413758-a-00038006.pdf. - Назва з екрану. - Дата звернення 11.01.2018.

6. Кара С. Проблема «заморожування» конфліктів: причини, особливості, перспективи [Електронний pecypc] / С. Кара // Український тиждень. - Режим доступу: http://tyzhden.ua/Politics/138471. - Назва з екрану. - Дата звернення 23.01.2018.

7. Припинення і пост-конфліктне врегулювання сепаратистських конфліктів: іноземний досвід і висновки для України [Електронний ресурс]: аналітична записка Відділу національної безпеки Національного інституту стратегічних досліджень // НІСД. - Режим доступу: http://www.niss.gov.ua/content/articles/files/separ konfl-66377.pdf. - Назва 3 екрану. - Дата звернення 20.01.2018.

8. Україна. Оцінка відновлення та розбудови миру [Електронний ресурс]: аналіз впливу кризи та потреб на Східній Україні / ООН. - Режим доступу: http://www.un.org.ua/images/RPA_V2_Ukr_pdf. - Назва з екрану. - Дата звернення 23.01.2018.

9. Gahramanova A. Peace strategies in "frozen" ethno-territorial conflicts: integrating reconciliation into conflict management [Електронний ресурс]: The case of Nagorno-Karabakh. / A. Gahramanova // Research Gate. - Режим доступу: https://www.researchgate.net/publication/45667071 Peace strategies in frozen ethnoterritorial conflict s_integrating_reconciliation_into_conflict_managementThe_case_of_Nagorno-Karabakh. - Назва 3 екрану. - Дата звернення 24.01.2018.

10. Martin P .The EU's Eastern Partnership, post-Soviet frozen conflicts and the war in Eastern Ukraine [Електронний pecypc] / P. Martin // Nouvelle-Europe. - Режим доступу: http://www.nouvelleeurope.eu/en/eu-s-eastern-partnership-post-soviet-frozen-conflicts-and-war-eastern-ukraine. - Назва 3 екрану. - Дата звернення 26.01.2018.

11. Post-Soviet 'frozen conflicts' [Електронний pecypc] / Euractiv. - Режим доступу: https://www.euractiv.com/section/armenia/linksdossier/post-soviet-frozen-conflicts/. - Назва з екрану. - Дата звернення 01.02.2018.

\section{References:}


1. Horbulin, V. (2016). Hybrid war: everything just starts ...Dzerkalo tyzhnia [Mirror of the week], [online] Available at: https://dt.ua/internal/gibridna-viyna-vse-tilki-pochinayetsya-_.html. [Accessed 20 December 2017]. Title from the dcreen.

2. Dodon, I. (2017). Transnistria may become part of either Ukraine or Moldova, but not the Russian Federation. Tsenzor. net [Censor. net], [online] Available at: https://ua.censor.net.ua/n462739. [Accessed 23 December 2017]. Title from the dcreen.

3. I. F. Kuras Institute of Political and Ethnic Studies of the National Academy of Sciences of Ukraine. (2014). Donbas in the ethnopolitical dimension. Kyiv: I. F. Kuras Institute of Political and Ethnic Studies of the National Academy of Sciences of Ukraine.

4. Ukrainian institute of strategies of global development and adaptation. (2017). Roadmap for the East-Ukrainian conflict as a form of organization of civic activity. [online] Available at: https://uisgda.com/ua/dorozhnya-karta-virishennya-shidnoukrainskogo-konfliktu-yak-forma-organizaciigromadyanskoi-aktivnosti.html. [Accessed 10 January 2018]. Title from the dcreen.

5. Institute of World Policy. (2016). Experience in resolving conflicts in the world. Lessons for Ukraine. [online] Available at: https://glavcom.ua/media/o-00413758-a-00038006.pdf. [Accessed 11 January 2018]. Title from the dcreen.

6. Kara, S. (2015). The problem of "freezing" conflicts: reasons, peculiarities, perspectives. Ukrainskyi tyzhden [Ukrainian week], [online] Available at: http://tyzhden.ua/Politics/138471. [Accessed 23 January 2018]. Title from the dcreen.

7. The National institute for Strategic Studies. Suspension and post-conflict settlement of separatist conflicts: foreign experience and conclusions for Ukraine: the National Security Division an analytical note. [online] Available at: http://www.niss.gov.ua/content/articles/files/separ konfl66377.pdf. [Accessed 20 January 2018]. Title from the dcreen.

8. The UN. (2015). Ukraine. An assessment of the recovery and peace building: an analysis of the impact of the crisis and needs in Eastern Ukraine. [online] Available at: http://www.un.org.ua/images/RPA_V2_Ukr_.pdf. [Accessed 23 January 2018]. Title from the dcreen.

9. Gahramanova, A. (2007). Peace strategies in "frozen" ethno-territorial conflicts: integrating reconciliation into conflict management: Thecaseof Nagorno-Karabakh. [online] Available at: https://www.researchgate.net/publication/45667071 Peace strategies in frozen ethnoterritorial conflict s integrating reconciliation into conflict managementThe case of Nagorno-Karabakh. [Accessed 24 January 2018]. Title from the dcreen.

10. Martin, P. (2017). The EU's Eastern Partnership, post-Soviet frozen conflicts and the war in Eastern Ukraine. Nouvelle-Europe. [online] Available at: http://www.nouvelle-europe.eu/en/eu-s-easternpartnership-post-soviet-frozen-conflicts-and-war-eastern-ukraine. [Accessed 26 January 2018]. Title from the dcreen.

11. Post-Soviet 'frozen conflicts'. (2016). Euractiv. [online] Available at: https://www.euractiv.com/section/armenia/linksdossier/post-soviet-frozen-conflicts/. [Accessed 1 February 2018]. Title from the dcreen.

(c) Семчинський К. В. 2018 